\title{
Character Education Through Zoom Cloud Meeting in Distance Learning to Improve Digital Ethnics in Civic Education Learning (Case Study in SMP Al-Fath BSD)
}

\author{
Zepi Khomara $^{1 *}$, Sapriya Sapriya ${ }^{2}$ \\ ${ }^{1,2}$ Universitas Pendidikan Indonesia, Bandung, Indonesia \\ "Corresponding author. Email: zefikhomara@gmail.com
}

\begin{abstract}
Now the world of education indonesia is faced with challenges that must be solved in the learning process. From teachers samapi many students are less able to maximize digitization and banayak complaints obtained due to the adaptation process of learning acceptance from face-to-face models and distance learning. Schools have challenges in realizing ethical values in virtual learning because of the gap between ethical theory and their applications in the real world. In the era of life activities from the economy, the world of education and health is forced to do daily activities with digital. But the reference material is in the process of learning and education for students. The implementation of learning is felt to be less able to adapt well from ethics when in learning to assignments made by students. So the purpose in this study produces how character education can be used as a reference in the application of virtual learning that can improve the ability and understanding of students. As well as raising the spirit of learning as before the pandemic.
\end{abstract}

Keywords: Character Education, Digital Ethnics.

\section{INTRODUCTION}

The Covid-19 pandemic that has spread throughout the world, including Indonesia, has affected many aspects of life, including education. Therefore, educational institutions must conduct the process of learning activities remotely. This means that students must continue to learn and teach even at home. Therefore, educators should design learning using online media. It is based on the decision of the Ministry of Education and Culture of the Republic of Indonesia on Circular Letter No. 4 of 2020 concerning the Implementation of Education Policy in Emergency Situations Against the Covid-19 Pandemic. Many efforts have been made to ensure that learning activities can continue without face-toface meetings. Technology, especially the internet, smartphones and laptops are now widely used to support distance education. Studying in the midst of the Covid-19 pandemic brought tremendous change when education at all levels, including junior high school, was suddenly 'forced' to adapt to independent learning) means. This is certainly not an easy task, as it is not perfectly prepared.

Distance education has become a challenge in the world of education improving important aspects of distance learning, including educational programs for teachers who use information and communication technology. For distance learning to run smoothly, teachers don't have enough basic technical skills (such as using a computer and connecting to the internet), but lessons without knowing how to use a device, recording software. Face-to-face interaction (fun learning video)). These techniques are very important when using e-learning platforms.

During the Covid-19 pandemic, the Government issued a policy on how to implement online and offline learning. In The Great Dictionary of Indonesia is interpreted in the network, connected through computer networks, the internet, and so on. During learning is implemented as the right step to be able to prevent and suppress the transmission of the Covid-19 virus, even students will not miss lessons as planned in the curriculum during the school year. Therefore, the learning done today is online that is remote in nature. Of course, it is a challenge for teachers in order to achieve learning outcomes, especially in the efforts of children's character education.

Character education is the creation of a school environment that assists students in the development of ethics, responsibility through models, and the teaching of good character through universal values (Berkowitz \&Bier, 2005:7). With learning conducted outside the school environment in this case using online learning that is remote, providing extra tasks and responsibilities and challenges for teachers 
to be able to create a learning environment in an effort to develop the ethics, responsibilities and character of the learner. Because the evaluation method of character education is one of them with direct observation by the teacher, who observes new attitudes or changes in attitudes that appear in students.

The use of zoom cloud meetings in elementary schools in major cities is a solution in creating fun learning and focused not only on results but also interactions built during the covid-19 pandemic. This is in accordance with what was conveyed by the Minister of Education, Nadiem Makarim "The principle of education policy during the Covid-19 pandemic is to prioritize the health and safety of students, educators, educational personnel, families, and the public in general, as well as considering the growth of learners and psychosocial conditions in an effort to fulfill educational services during the Covid-19 pandemic.," (news.okezone.com,2020). As conveyed by the Minister of Education, during the covid 19 pandemic, learning should focus on meaningful learning, which is learning that connects new learning with previously owned learning in cognitive structure in learners, (Ausubel, 1963).

The use of cloud meeting zoom is also considered effective, because each student has a different learning style. There are at least three types in learning styles, namely visual, auditorial, and kinesthetic, (Deporter \&Hernacki, 2000). Although each student has all three learning styles, there is always one dominant learning style, Arlien, et al., 2014). In learning using zoom cloud meeting dominant children using visual and audio learning styles can follow the learning well because between students can see each other and interact. In addition, the use of zoom meetings is considered to support distance learning because it can facilitate students in absorbing materials delivered by educators because it is more appropriate as a learning medium. (Ismawati, et al., 2020). In the process of distance learning that is being implemented, zoom cloud meeting acts as a virtual classroom, because through zoom cloud meeting face-to-face activities can be carried out.

\section{THEORETICAL REVIEW}

\subsection{Character Education}

Character Education in (Komalasari, 2017) is usually defined, so there are communities such as families and schools to build Character. Personality development in the family can be developed through family habits, religious programs, age, and parental-led family education. Schools also play an excellent role in character education. In schools, this process can be internalized through learning activities, extracurricular activities, school cultural performances, competitions, etc. Character education does not exist without reason and is present in the form of social and public interests in moral crises and internal conflicts. This is a new hope to improve the situation by internalizing character education through school education. In Indonesia, character education is based on pancasila ideology in practice (Huat, 1993).

Character Education is often regarded as moral education, and in this case (Smith, 2006) it is stated that moral education is Character education, and this phrase explains that personal education is part of education. Hiil's statement brings about and distinguishes the history of value education in America by consistently linking religious, ethical, and social issues in education with value education (Qoyyimah, 2016). In this statement (Hill, 1991), indirectly, character education believes that character education contains the desired standard of value or traits in the value education curriculum. So, it is clear that the standard value of 18 characters of Indonesian language from Hill's point of view. In Indonesia, the values of character education are expected to increase harmony, civilization, and peace, and are offered to eliminate internal conflicts, moral corruption and corrupt practices, involvement and dictatorship (KKN). Welfare in all areas of society (Noah, 2011).

(Ricona 1992) character education is likened to a pavilion. Because to achieve the educational goals of the character requires a lot of complex approaches to build an outstanding character. Character education based on Rikona's concept can be divided into three elements: first knowing kindness, loving, and doing good. These three elements are a series of character education courses, the application begins with giving understanding to students about the meaning of goodness, then inviting students to love and love goodness or virtue, and finally students can practice kindness. It's in their own lives. About character education.

(Khan, 2010) explained that character education is a way to shape the habit of thinking and acting in accordance with moral values so that we can live in harmony with society. True character education is not just about good and bad behavior, but about adopting behavior based on prevailing moral values. Personality programs include good habits, awareness, caring and a high commitment to implementing such good behavior in daily life (Hermino, 2014). The main purpose of character education itself is to connect the development of lasting values with the creation of ethical behaviors in the school environment and society (Kesuma, 2012).

Character Education, explained by Suyanto (Asmani, 2011), is a character education that prioritizes 
aspects of early knowledge, feelings, and behavior. Based on the assumption that character education is a system that challenges aspects of teachers and school culture and transmits values to school residents (Muslich, 2011), the human character that wants to be achieved this value of perseverance is a noble human being.

Character education is an absolute thing to be implemented because basically all teachers as educators have the same goal in shaping the character of the nation. Not necessarily character education becomes the responsibility of moral education or ethics and education Pancasila (Santika, 2019:79), but it becomes the responsibility of all fields of study. Therefore, when the implementation of the curriculum 2013, the balance of the realm of cognitive, affective and psychomotor learning became an absolute ouput as part of the improvement of the character of the nation. Character is a person's character, or ahlak obtained from internalization with his environment.

One's character will be good if it is based on moral and ethical values that apply and are agreed upon in society. Lickona (1992). "emphasizes the importance of three components of good character, namely moral knowing or knowledge about morals, moral feeling or feelings about morals, and moral action or moral deeds". Good characters will appear after the three characters can be fulfilled in the learner.

Character education has three main functions. First, the function of formation and development of potential. Character education shapes and develops the potential of students to be good-minded, kind-hearted, and behave in accordance with the philosophy of Pancasila. Second, the repair and strengthening functions. Character education improves and strengthens the role of families, educational units, communities, and governments to participate and be responsible in developing the potential of citizens and nation building towards a developed, independent, and prosperous nation. Third, the filter function. Character education sorts out the culture of the nation itself and filters the culture of other nations that are incompatible with the nation's cultural values and the character of a dignified nation (Zubaidi, 2011:18).

Thus the formation of the character of this nation should involve the synergy of the three components of education, among others informal, formal and non-formal education. Facing the challenges of the era that is now entering the era of industrial revolution 4.0 which is full of advances in digitalization technology, planting and strengthening the character of the nation is vital and urgent. The development of individualistic, hedonistic, materialistic values and so on is a bad impact of the current globalization and industrial revolution 4.0. If this is allowed it will have a bad influence on the sufness of national life that no longer reflects the values of the nation's personality.

\subsection{E-Learning}

E-learning is one form of learning model that is facilitated and supported by the use of information and communication technology. E-learning has characteristics, among others (Clark \&Mayer 2008: 10): 1) has content relevant to the purpose of learning; 2) use instructional methods, such as example presentation and exercises to improve learning; 3) use media elements such as words and images to convey learning materials; 4) enables direct teacher-centered learning (synchronous e-learning) or designed for asynchronous e-learning; 5) build understanding and skills related to learning objectives either individually or improve group learning performance. While according to Rusman et al (2011: 264) e-learning has characteristics, among others (a) interactivity (interactivity); (b) independency; (c) accessibility; (d) enrichment. E-learning can be defined as a form of information technology applied in the field of education in the form of cyberspace. The term e-learning is more appropriately intended as an effort to transform the learning process in schools or universities into a digital form bridged by internet technology (Munir, 2009: 169).

While online learning is a learning that is delivered through online and facilitates both parties. Virtual learning is learning that only uses the internet. While web based learning is learning materials uploaded to the website to be studied by students. Thus, e-learning cannot be confused with these terms, but online or virtual learning or web-based learning is part of e-learning in the learning process, (Simanihuruk.et al., 2019:5).

\subsection{Zoom Cloud Meeting Application}

Zoom Cloud Meeting is included in learning elearning video conference. Before getting to know zom cloud meeting application, please be aware that there are at least eight advantages of video conferencing in Education (ez Talk,2019). By using video conferences students and educators can interact with each other and collaborate between schools in education and discussion. During learning using video conferences, students do not have to leave the home to receive learning materials. This is very appropriate to the current state of pandemic covid-19.

The zoom meeting cloud application is an application used as a remote communiqué media by combining video conferencing, chat, online meetings and mobile collaboration. Some companies already use this application as a medium in conducting meetings, it is because this application has good quality, companies 
that are already included in the Fortune 500 already use this service. (Wibawanto, 2020). In addition to the company, when the pandemic occurred the use of zoom meting by teachers was at a percentage of 71 percent, superior to other media, (Nasir, 2020:613).

\subsection{Digital Ethics}

Paying attention to the ethics of communication on social media is one of the things that is important to do. How not, social media is now part of the way people communicate most. Ease of communication can be found with this social media. The form is also diverse, where basically the communication that will be done is usually a wide network and interconnected with each other. Therefore, if in communicating on social media does not pay attention to ethics, then it could be that someone becomes troubled to cause conflict with others.

Social media is one form of digital communication today. There are indeed distinctive social media traits that we can know about. Through social media, many people can connect easily. The dissemination of information is relatively faster with the presence of social media. This is a type of online communication method included. Here are some ethics to keep in mind when communicating on social media:
a. Always pay attention to the use of sentences
b. Be careful when using letters
c. Pay attention to the font color selection
d. Choosing the right symbols and icons
e. Use the appropriate language
f. Respond promptly
g. Provide information that has clear references
h. Does not provoke opposition

\section{RESEARCH METHODS}

This research uses a qualitative approach with a case study method. Case studies or called field research, namely research to investigate focused on an event, stage, activity, program, event or group of people. A case is limited by time and activities, then the researcher explores the information as a whole by applying a series of procedures to collect data over the specified time. Participation of the research that will be carried out by researchers in qualitative research is people who are in direct contact with students who carry out distance learning using the Zoom cloud meeting application, then teachers who teach and parents as supervisors of online learning. Students and participation were taken from students, teachers and guardians of SMP Al-Fath BSD students. This research was conducted by triangulation of data collection through observation, interviews with supporting sources and documentation as a reinforcement of the validity of the qualitative research data.

\section{RESULT AND DISCUSSION}

In distance learning experienced by all students due to the covid-19 pandemic, the values of character education taught in PKN learning are included. Because of the problems faced in distance learning that teachers complain about, there are many students' ethics in digital communication that are lacking and tend to need ethical education in digital itself. From the results of research conducted on teachers who teach in learning, some complain that students disappear during virtual learning. From who turned off the camera and called there was no response. I don't know if it's just going to class or having network problems. But in the end the teacher understood with good prejudice that the students disappeared due to network constraints.

Then the next problem is in the assignment. Some students find it difficult to collect assignments according to schedule and do them at the end of assignment collection, but in doing assignments they take from internet sources without including the source and not changed first. Even some students did not collect assignments due to several factors. One of them is that the student does not know the assignment given because he is rarely zoomed in or in a virtual class.

The next problem faced is the pattern of students when zooming in, many students turn off the camera and find it difficult to respond when asked. Communication barriers are faced by student teachers who are difficult to contact and poor message communication patterns from the time they start contacting the teacher and after. However, when conducting interviews with students, the problems faced by some students answered that they were due to network problems so that students found it difficult to take virtual classes and when zooming in, students were reluctant to ask questions again regarding the material or assignments given.

As a result, these students are confused about their assignments and do not even do the assignments given by the teacher. Their reluctance to contact the teacher when they do not understand is what causes problems in learning. Sometimes students complain when communicating with teachers, the problem they face is the pattern of delivering messages that are not appropriate, resulting in poor communication between teachers and students. Furthermore, interviews with some other students revealed that there was boredom in distance learning, they admitted that when learning sometimes only entered the virtual zoom class, then turned off the sound and turned off the video, after that it was continued by doing other activities. Some are asleep while zooming in and playing online games. The student left the class. Students admit that online learning is boring. 
Then this research was continued with the cultivation and education of character education, by instilling character values and ethics of digital communication in students which was carried out in PKN subjects. By explaining values and ethics as well as delivering digital ethics, students slowly begin to improve digital communication patterns.

\section{CONCLUSION}

Based on the results of the research conducted, the authors can draw conclusions about "Character Education Through Zoom Cloud Meetings in Distance Learning to Improve Digital Ethics in PKN Learning" Students' character education is needed in starting learning to get used to telling and giving examples to students how digital communication patterns and the delivery of character values make students better prepared for distance learning. From the problems seen there needs to be an introduction before starting the learner from the education of planting ethical and moral values with an approach of 18 values of character education. And 8 patterns of delivering digital ethical communication in learning

\section{REFERENCES}

[1] Agustin, Mubiar. (2020). Permasalahan Bealajar dan Inovasi Pembelajaran (Cet.3). Bandung: PT Refika Aditama.

[2] Amiroh.(2012). Kupas Tuntas Pembangunan elearning dengan Learning Management System Moodle. Sidoarjo: Genta Group Production.

[3] Amri, Sofan, dkk. 2011. Implementasi Pendidikan Karakter Dalam Pembelajaran. Jakarta: PT. Prestasi Pustakarya.

[4] Anugraha, Andri. (2020). Hambatan, Solusi dan Harapan: Pembelajaran Daring Selama Masa Pandemi Covid-19 Oleh Guru Sekolah Dasar. Scholaria: Jurnal Pendidikan dan Kebudayaan. Vol.10 (3). Hal. 282-289.

[5] Asmani, Jamal Ma'mur.2011. Buku Panduan Internalisasi Pendidikan Karakter di Sekolah. Jogjakarta: DIVA Press.

[6] Belawati, Tian dkk.1999. Pendidikan Terbuka Dan Jarak Jauh. Jakarta: Universitas Terbuka.

[7] Bire, Arylien Ludji, dkk. (2014). Pengaruh Gaya Belajar Visual, Auditorial, Dan Kinestetik Terhadap Prestasi Belajar Siswa. Vol 44 (2). Hal 168-174.

[8] DePorter, B. \& Hernacki, M. (2000). Quantum Learning. Edisi Revisi. Bandung: Kaifa.

[9] Hadi, S. (1989). Metode Research. Yogyakarta: Andi offset.

[10] Hakim, T. (2005). Belajar secara efektif. Jakarta: Niaga Swadaya.

[11] Herdiansyah, H. (2011). Metodologi Penelitian Kualitatif untuk Ilmu-Ilmu Sosial. Jakarta: Salemba Humanika.
[12] https://news.okezone.com/read/2020/09/03/65/2 271791/mendikbud-pastikan-kebijakanpembelajaran-di-masa-pandemi-covid-19terlaksana diakses pada 19 oktober 2020 pukul 21.01

[13] Hyder, B. K., Kwinn, A., Miazga, R., Murray, M., \& Brandon, B. (2007). The elearning Guild's Handbook on Synchronous e-Learning. The Elearning Guilduild. https://doi.org/10.1093/bioinformatics/bth173

[14] I Wayan. (2020). Pendidikan Karakter Dalam Pembelajaran Daring. Jurnal VCEJ, Vol 3 No 1.

[15] Ismawati, Dwi dan Iis Prasetyo. (2020). Efektivitas Pembelajaran Menggunakan Video Zoom Cloud Meeting pada Anak Usia Dini Era Pandemi Covid-19. Jurnal Obsesi: Jurnal Pendidikan Anak Usia Dini. Vol. 5 (1). Hal. 665 675

[16] Kean Wah, L., Choon Keonga, T., and Denis, Shi Ing, N. (2013). "Understanding the Blended Learning Experiences of English Language Teachers in a Distance TESL Degree Programme in Malaysia," J. Teknol. Soc. Sci., vol. 65 , no. 2 .

[17] Kemendikbud. (2017). Penguatan Pendidikan Karakter: Modul Pelatihan Bagi Kepala Sekolah. Jakarta: Puskurbuk Jakarta.

[18] Kemendiknas. (2011). Pedoman Pelaksanaan Pendidikan Karakter [Buku pedoman pendidikan karakter]. Jakarta: Puskurbuk Jakarta.

[19] Kusuma, Wijaya, dkk. (2020). Menciptakan Pola Pembelajaran yang Efektif di Rumah. Jakarta: Tata Akbar.

[20] Musdaeni, Syahruni, dkk. (2020). Pendidikan Karakter Melalui Pembelajaran Berbasis Ict.

[21] Naim, N. (2011). Dasar-dasar Komunikasi Pendidikan. Jogjakarta: ArRuzz Media.

[22] Sandiwarno, S. (2016). Perancangan Model ELearning Berbasis Collaborative Video Conference Learning Guna Mendapatkan Hasil Pembelajaran yang Efektif dan Efisien. Jurnal Ilmiah FIFO, 8(2), 191.

[23] Seok, Soonhwa. (2008). The aspect of elearning. International Journal on ELearning, Proquest, 7(4), 725-741.

[24] Slameto. (2010). Belajar dan faktor-Faktor yang Mempengaruhinya. Jakarta: Rineka Cipta.

[25] Sudarma, K., \& Nugraheni, F. (2006). Pengaruh motivasi berprestasi dan strategi belajar efektif terhadap prestasi belajar akuntansi. Dinamika Pendidikan, Vol. 1 (1).

[26] Moleong, L. (2014). Metode Penelitian Kualitatif Edisi Revisi. Bandung: PT Remaja Rosdakarya.

[27] Sugiyono. (2015). Metode Penelitian Kombinasi (Mix Method). Bandung: Alfabeta.

[28] Sukardi. (2005). Metode Penelitian Pendidikan:Kompetensi dan Prakteknya. Jakarta: Bumi Aksara. 
[29] Tanzeh, A., \& Suyitno. (2006). Dasar-dasar penelitian. Surabaya: Elkaf.

[30] Warsita, Bambang.2011. Pendidikan Jarak Jauh, Perencanaan, Pengembangan, Implementasi, Dan Evaluasi Diklat. Bandung: PT. Remaja Rosdakarya.

[31] Wahab, A. A. dan Sapriya. (2011). Teori dan Landasan Pendidikan Kewraganegaraan. Bandung: ALFABETA.

[32] Winataputra, U. S. (2001). Jati Diri Pendidikan Kewarganegaraan Sebagai Wahana Sistemik Pendidikan Demokrasi (Suatu Kajian Konseptual dalam Konteks Pendidikan IPS). Disertasi. Bandung: Universitas Pendidikan Indonesia.
[33] Winaya, A. M. (2020). Pembelajaran Daring sebagai "New Normal" Sekolah di masa Pandemi Webminar Nasional. Program Studi pendidikan Sekolah Dasar Universitas dwijendra, 19 Juni 2020, Denpasar

[34] Yulia Citra. 2015. Pelaksanaan Pendidikan Karakter Dalam Pembelajaran Tersedia pada: http://ejournal.unp.ac.id/index.php/jupekhu/arti cle/viewFile/795/666

[35] Zuchdi, Darmiyati, Prasetya, Zuhdan Kun,dan Masruri Muhsinatun Siasah. 2010. "Pengembangan Model Pendidikan Karakter Terintegrasi dalam Pembelajaran Bidang Studi di Sekolah Dasar, ”. Cakrawala Pendidikan. 1 (3). 2010. Edisi Khusus Dies Natalis UNY 